DOI: https://doi.org/10.24127/ajpm.v10i3.3650

\title{
LITERASI SPASIAL SISWA SMP DALAM MENYELESAIKAN SOAL GEOMETRI DITINJAU DARI PERBEDAAN GAYA BELAJAR
}

\author{
Indah Prasetya Ningsih $^{1 *}$, Mega Teguh Budiarto ${ }^{2}$, Siti Khabibah ${ }^{3}$ \\ $1^{*, 2,3}$ Pascasarjana Universitas Negeri Surabaya, Jawa Timur, Indonesia \\ ${ }^{*}$ Corresponding author. \\ E-mail: $\quad$ indah.18006@mhs.unesa.ac.id ${ }^{1 *}$ \\ megatbudiarto@unesa.ac.id ${ }^{2}$ \\ sitikhabibah@unesa.ac.id ${ }^{3)}$
}

Received 31 March 2021; Received in revised form 08 September 2021; Accepted 22 September 2021

\begin{abstract}
Abstrak
Tujuan pada penelitian ini adalah untuk mendeskripsikan profil literasi spasial siswa dalam menyelesaikan soal-soal geometri berdasarkan tinjauan perbedaan gaya belajar. Jenis penelitian yang digunakan adalah penelitian deskriptif dengan pendekatan kualitatif. Subjek penelitian ini adalah tiga siswa kelas VIII yang berkemampuan matematika tinggi dengan masing-masing gaya belajar visual, gaya belajar auditori, dan gaya belajar kinestetik. Instrumen pendukung pada penelitian ini adalah 1) angket gaya belajar; 2) tes kemampuan matematika; 3) tugas geometri; dan 4) pedoman wawancara. Hasil Penelitian ini adalah subjek dengan gaya belajar visual tergolong baik dalam domain visualisasi spasial dan penalaran spasial, tetapi lemah dalam komunikasi spasial. Subjek dengan gaya belajar auditori tergolong baik dalam visualisasi dan komunikasi spasial tetapi lemah pada penalaran spasial. Serta subjek gaya belajar kinestetik tergolong baik dalam komunikasi spasial tetapi lemah pada penalaran spasial.
\end{abstract}

Kata kunci: Gaya belajar; literasi spasial; geometri.

\begin{abstract}
The purpose of this study is to describe the profile of students spatial literacy in solving geometry problems based on a review of differences in learning styles. The type of research used is descriptive research with a qualitative approach. The subjects of this study were three grade VIII students who had high mathematical abilities with their respective visual learning styles, auditory learning styles, and kinesthetic learning styles. The supporting instruments in this study were 1) a learning style questionnaire; 2) math ability test; 3) geometry task; and 4) interview guide. The results of this study are subjects with visual learning styles classified as good in the domain of spatial visualization and spatial reasoning, but weak in spatial communication. Subjects with auditory learning style are good in visualization and spatial communication but weak in spatial reasoning. And the subject of kinesthetic learning styles is good in spatial communication but weak in spatial reasoning.
\end{abstract}

Keywords: Learning style; spatial literacy; geometry.

This is an open access article under the Creative Commons Attribution 4.0 International License

\section{PENDAHULUAN}

Perkembangan teknologi, peningkatan kesadaran akan kebutuhan sosial dan ekonomi, serta keanekaragaman budaya mengakibatkan munculnya literasi-literasi baru di berbagai bidang salah satunya literasi spasial. Literasi spasial adalah pengembangan dari proses berpikir spasial untuk meningkatkan pengetahuan dan keterampilan dalam berpikir, bertindak, dan bernalar tentang objek-objek dan hubungan spasial dalam kehidupan sehari-hari dan lingkungan sekitar. (Bednarz, 2011; Abidin, 2018). 
Literasi spasial sedikit diartikan secara spesifik, tetapi lebih sering dibahas sebagai kemampuan spasial dan berpikir spasial. (Jarvis,2011). Literasi spasial sangat penting bagi siswa karena dapat membantu siswa dalam memahami materi geometri, dan membantu lebih mengenal dan beriteraksi dengan lingkungan sekitar. Literasi spasial juga dapat diaplikasikan dalam disiplin ilmu STEM dan merupakan salah satu faktor yang dibutuhkan dalam berbagai jenis pekerjaan seperti arsitektur, insinyur, air traffic controller, atlet, dan seniman. Sehingga kemampuan literasi spasial diperlukan siswa untuk lebih unggul dalam berbagai bidang dan mampu bersaing secara global.

Salah satu standar internasional yang dapat mengukur atau mengevaluasi literasi spasial adalah PISA (Lane, et.al. 2019) yang termasuk ke dalam konten space and shape pada literasi matematika

(Yusmin,2016).

Kemampuan siswa pada konten space and shape tergolong masih rendah. Hal ini dapat dilihat pada data PISA dimana skor rata-rata prestasi siswa Indonesia pada kategori space and shape adalah 383 dengan skor rata-rata OECD 490 (Piacentini,2016). Hal ini sejalan dengan penelitian (Maulana, 2016) skor rata-rata kategori space and shape lebih rendah daripada kategori change and relationship. Selain itu siswa mengalami kesulitan dalam menguasi materi geometri yang erat kaitannya dengan literasi spasial yang dapat dilihat dari persentase penguasaan materi Ujian Nasional siswa SMP sebesar 47,19\% (2015/2016), 48,57\% (2016/2017), 41,40\%(2017/2018), dan $42,27 \% \quad(2018 / 2019)$ pada bidang geometri dan pengukuran (PUSPENDIK, 2019). Hal ini menunjukkan bahwa lebih dari setengah popoulasi siswa Indonesia di tingkat SMP mengalami kesulitan dalam menguasai materi geometri dan pengukuran. Adapun beberapa penelitian yang menunjukkan kesulitan siswa dalam geometri antara lain lemahnya konsep-konsep geometri, kesulitan dalam memecahkan masalah geometri, dan rendahnya dalam penalaran siswa dalam objek-objek geometri. (Budiarto \& Artiono, 2019; Subaidah,et.al. 2017).

Kesulitan dalam memecahkan soal geometri bergantung pada bagaimana cara siswa dalam memecahkan masalah tersebut. Siswa memiliki cara tersendiri untuk memperoleh, mengolah, dan menyimpan informasi yang disebut dengan gaya belajar. Terdapat beberapa jenis gaya belajar, salah satunya gaya belajar VAK (Visual, Auditori, dan Kinestetik). Beberapa penelitian mengatakan bahwa siswa dengan gaya belajar visual memiliki kemampuan spasial yang lebih unggul daripada gaya belajar auditori dan gaya belajar kinestetik (Alfaruqi \& Lutfianto, 2018; Fitri, 2017).

Berdasarkan permasalahanpermasalahan tersebut, penelitian ini membahas tentang literasi spasial siswa SMP dalam menyelesaikan soal geometri ditinjau dari perbedaan gaya belajar. Pada penelitian ini komponen literasi spasial yang akan dibahas adalah visualisasi spasial, penalaran spasial, dan komunikasi spasial. (1) Visualisasi spasial adalah suatu proses yang menghasilkan representative kognitif tentang objek-objek spasial melalui gambar visual yang dilakukan oleh perbuatan fisik atau dari representasi eksternal (Moore-Russo,et.al.2013). (2) Penalaran spasial adalah proses mengenali, mengatur, membandingkan, memanipulasi sifat spasial dan hubungan antara konsep-konsep spasial 
(Moore-Russo,et.al.2013; Lowrie,2018; Mulligan, 2015). (3) Komunikasi spasial adalah penyampaian ide-ide atau gagasan-gagasan kepada orang lain secara langsung maupun secara tulisan tentang objek-objek spasial dan hubungan antar objek-objek spasial.

Soal-soal geometri yang diberikan berupa soal uraian pada materi bangun ruang sisi datar yang sesuai dengan konten space and shape. Gaya belajar untuk menjelaskan berbagai cara agar siswa memperoleh pengetahuan. (Nja, 2019). Perbedaan gaya belajar yang dibahas adalah gaya belajar VAK meliputi gaya belajar visual, gaya belajar auditori, dan gaya belajar kinestetik (dePorter, 2014).

Berdasarkan latar belakang tersebut, maka tujuan penelitian ini adalah untuk mendeskripsikan profil literasi spasial siswa dengan gaya belajar visual, auditori, dan kinestetik dalam menyelesaikan soal geometri.

\section{METODE PENELITIAN}

Jenis penelitian ini adalah penelitan deskriptif dengan pendekatan kualitatif. Penelitian ini menggunakan jenis penelitian deskriptif karena betujuan mendesripsikan kemampuan literasi spasial siswa dalam menyelesaikan soal geometri yang dtinjau dari perbedaan gaya belajar (visual, auditori, dan kinestetik). Penelitian ini menggunakan pendekatan kualitatif karena meneliti kondisi objek yang alamiah bukan hasil perlakuan atau eksperimen.

Penelitian ini dilakukan pada SMP Islam Roushon Fikr. Subjek penelitian adalah tiga siswa SMP kelas VIII Kreatif tahun ajaran 2020/2021 yang mewakili gaya belajar VAK (Visual, auditori, dan kinestetik), berjenis kelamin sama yaitu kelamin laki-laki dan mempunyai matematika tinggi setara. Sekolah yang dipilih sebagai lokasi penelitian adalah SMP Islam Roushon Fikr dan kelas yang dipilih adalah kelas VIII Kreatif karena berdasarkan pengamat peneliti dan guru serta hasil Ujian Tengah Semester Genap. Penelitian ini mempertimbangkan bahwa siswa telah mendapatkan materi bangun ruang sisi datar. Sebanyak 34 siswa diberikan instrumen tes kemampuan matematika dan angket gaya belajar yang kemudian dianalisis dan diambil tiga subjek siswa.

Tiga subjek penelitian yang sudah terpilih kemudian diberi penugasan yang berisi soal-soal geometri dan sesuai dengan indikator literasi spasial, kemudian dilanjutkan dengan wawancara untuk mengetahui bagaimana literasi spasial setiap siswa. Data yang diperoleh dalam penelitian ini berupa: 1) data hasil angket gaya belajar dan data tes kemampuan matematika yang diberikan setiap siswa untuk mendapatkan subjek penelitian dengan gaya belajar visual, auditori, dan kinestetik yang berkemampuan setara yakni berkemampuan tinggi; 2) data hasil penugasan geometri yang berupa soal uraian yang diberikan setiap subjek penelitian yang bertujuan untuk mengetahui literasi spasial setiap subjek; 3) data hasil wawancara setiap subjek penelitian.

Instrumen yang digunakan dalam penelitian ini diantaranya yaitu: 1) Tes Kemampuan Matematika (TKM); 2) angket gaya belajar; 3) Tugas geometri (TG); 4) pedoman wawancara. Teknik pengumpulan data yang digunakan dalam penelitian ini adalah 1) metode angket; 2) metode tes; 3) metode tugas; 4) metode wawancara. Untuk menguji kevalidan dalam penelitian ini dilakukan triangulasi waktu. Triangulasi dilakukan untuk menguji kredibilitas data. Penugasan dan wawancara dilakukan sebanyak dua kali dalam 
waktu yang berbeda dan data yang didapatkan menunjukkan kecenderungan yang sama maka data tersebut dikatakan valid dan kredibel.

Teknik analisis data yang digunakan pada penelitian ini adalah pendekatan kualitatif dengan tahapan sebagai berikut: 1) data hasil angket gaya belajar akan dianalisis dan direkapitulasi berdasarkan kelompok gaya belajar (gaya belajar visual, gaya belajar auditori, dan gaya belajar kinestetik), setiap kelompok gaya belajar diambil satu subjek. 2) data tes kemampuan matematika dianalisis menggunakan rubrik penskoran seperti pada Tabel 1. 3) Data hasil penugasan geometri dan wawancara direduksi, setelah itu melakukan penyajian data dan yang terakhir menarik kesimpulan berdasarkan data hasil penugasan dan wawancara.

Tabel 1. Rubrik penskoran TKM

\begin{tabular}{ccc} 
No & $\begin{array}{c}\text { Total Skor } \\
\text { Angket }\end{array}$ & $\begin{array}{c}\text { Kemampuan } \\
\text { Matematika }\end{array}$ \\
\hline 1 & $80 \leq x \leq 100$ & Tinggi \\
2 & $70 \leq x<80$ & Sedang \\
3 & $0 \leq x<70$ & Rendah \\
\hline
\end{tabular}

\section{HASIL DAN PEMBAHASAN}

\section{Literasi Spasial Siswa Gaya Belajar Visual}

Hasil literasi spasial siswa dalam menyelesaikan soal-soal penugasan geometri untuk subjek VS pada soal nomor satu sampai dengan nomor empat dapat dilihat pada gambar 1.

Berdasarkan hasilnya, subjek VS dapat menyelesaikan soal ke-1 dan ke-2 dengan membuat gambar sketsa tenda secara tepat dan lengkap serta menyertakan keterangan gambar yaitu ukuran unsur-unsurnya berdasarkan informasi yang didapatkan maupun tidak didapatkan. Subjek VS juga dapat mengubah gambar tiga dimensi menjadi dua dimensi dengan tepat dan lengkap. Pada soal nomor 2 subjek VS dapat membuat rancangan pintu masuk dan pintu keluar dengan menggambar sketsa pintu yang persis seperti pintu tenda asli. Sedangkan untuk soal nomor 4, subjek VS dapat membuat gambar dengan posisi yang tepat dengan melihat dari sudut pandang yang benar dan tepat. Serta soal nomor 5, subjek VS dapat menghitung volume tenda pertama dengan tepat tetapi tidak tepat dalam menghitung volume tenda kedua, serta subjek VS memberikan alasan perbedaan volume didasarkan oleh perbedaan bentuk dan rumus.

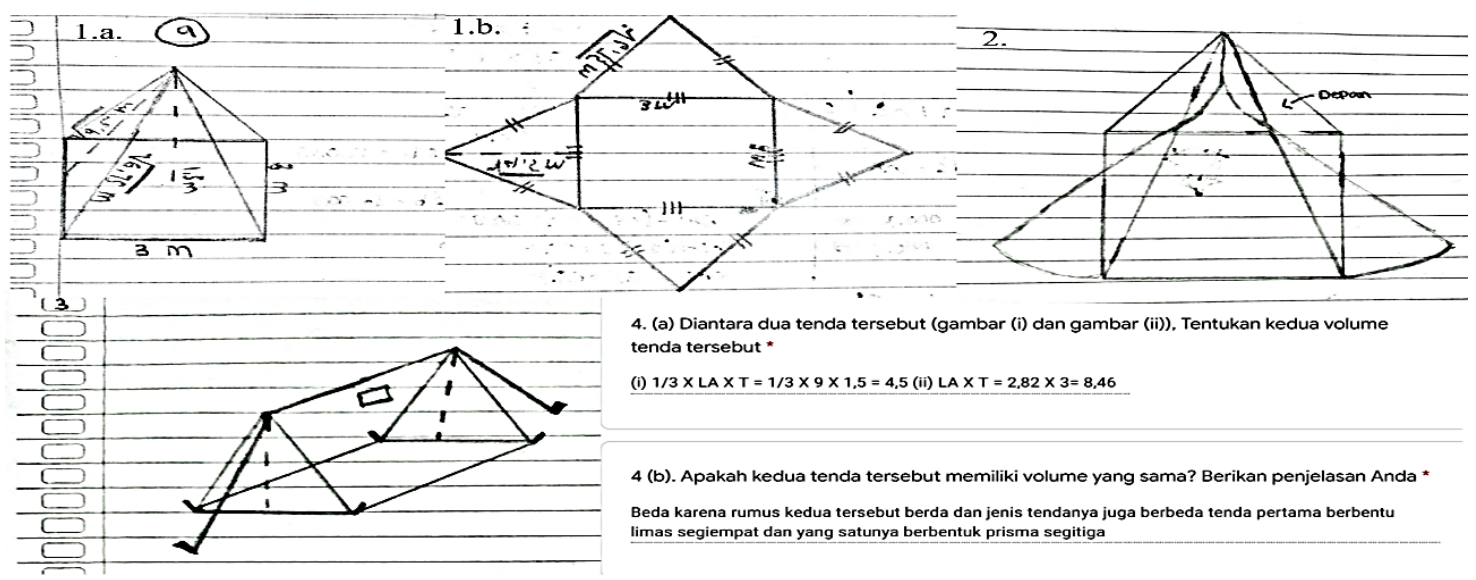

Gambar 1. Jawaban subjek VS pada soal nomor 1-4 
DOI: https://doi.org/10.24127/ajpm.v10i3.3650

Berdasarkan data hasil tugas-1 dengan wawancara-1 dan tugas-2 dengan wawancara-2 diperoleh bahwa kedua data tersebut cenderung sama, sehingga dapat disimpulkan bahwa data literasi spasial subjek VS dalam menyelesaikan soal-soal geometri adalahh valid. Hasil analisis wawancara subjek VS pada tugas-1 dan tugas-2 dapat disimpulkan siswa dapat menggambar sketsa bentuk tiga dimensi limas secara tepat dan lengkap dengan menuliskan ukuran setiap unsur dengan detail. subjek juga dapat mengubah bentuk tiga dimensi menjadi bentuk dua dimensi, menyelesaikan soal menggunakan konsep, representasi, dan keknik yang melibatkan dimensi, menentukan posisi benda pada bangun tiga dimensiyang dilihat dari sudut pandang berbeda, serta menyampaikan ide-ide yang berkaitan dengan bangun tiga dimensi secara tulisan. Untuk lebih jelasnya dapat dilihat pada Tabel 2

Tabel 2. Profil literasi spasial subjek VS dalam menyelesaikan soal-soal geometri

\begin{tabular}{|c|c|c|}
\hline No & Domain & $\begin{array}{r}\text { Interpretasi konvergensi } \\
\end{array}$ \\
\hline 1. & $\begin{array}{l}\text { Visualisasi } \\
\text { Spasial }\end{array}$ & $\begin{array}{l}\text { a. Menggambar sketsa bangun ruang limas dengan tepat } \\
\text { berdasrkan informasi yang didapatkan. } \\
\text { b. Menuliskan keterangan ukuran unsur-unsur dengan lengkap dan } \\
\text { detail. } \\
\text { c. Konsisten dalam menuliskan satuan pada setiap unsur. }\end{array}$ \\
\hline 2. & $\begin{array}{l}\text { Penalaran } \\
\text { Spasial }\end{array}$ & $\begin{array}{l}\text { a. Memahami maksud dari bentuk dua dimensi dan menggambar } \\
\text { sketsa bentuk dua dimensi dari bentuk dimensi dengan tepat dan } \\
\text { proporsiona serta menuliskan ukuran setiap unsur dengan tepat } \\
\text { dan lengkap. } \\
\text { b. Menggambar sketsa pintu keluar dan pintu masuk dengan tepat } \\
\text { dan sesuai dengan pintu tenda asli. } \\
\text { c. Meggambar sketsa tenda dengan posisi yang tepat dan dilihat } \\
\text { dari sudut pandang yang tepat. }\end{array}$ \\
\hline 3. & $\begin{array}{l}\text { Komunikasi } \\
\text { Spasial }\end{array}$ & $\begin{array}{l}\text { a. Menyampaikan ide-ide yang berkaitan dengan bangun ruang } \\
\text { geometri secara tulisan dengan membuat alasan perbedaan } \\
\text { kedua volume. } \\
\text { b. Menghitung volume tenda pertama dengan tepat. } \\
\text { c. Menghitung volume tenda kedua dengan tidak tepat. }\end{array}$ \\
\hline
\end{tabular}

Berdasarkan data yang disajikan, disimpulkan bahwa literasi spasial subjek VS baik dan tidak mempunyai kekurangan pada domain penalaran spasial. Hal ini tidak sejalan dengan penelitian (Moore-Russo,et.al.2013) bahwa kemampuan literasi spasial mempunyai banyak kekurangan dalam memecahkan masalah pada domain penalaran. Selain itu subjek VS memiliki literasi spasial yang baik pada domain visualisasi spasial dan penalaran spasial tetapi masih kurang baik pada komunikasi spasial, hal ini sejalan dengan penelitian (Fitri, 2017) yang menyatakan bahwa siswa dengan gaya belajar visual mempunyai kemampuan spasial yang lebih baik daripada siswa dengan gaya belajar auditori dan kinestetik.

\section{Literasi Spasial Siswa Gaya Belajar Auditori}

Hasil literasi spasial siswa dalam menyelesaikan soal-soal penugasan geometri untuk subjek $\mathrm{AD}$ pada soal nomor satu sampai dengan nomor empat dapat dilihat pada Gambar 2. 
DOI: https://doi.org/10.24127/ajpm.v10i3.3650

Berdasarkan hasilnya, subjek AD dapat menyelesaikan soal ke-1 dan ke-2 dengan menggambar sketsa secara tepat dan lengkap berdasarkan informasai yang didapatkan tetapi kurang konsisten dalam menuliskan satuan pada unsurunsur bangun ruang tersebut. Subjek $A D$ juga dapat mengubah gambar tiga dimensi menjadi dua dimensi dengan tepat. Pada soal nomor 2, subjek AD menggambar sketsa pintu keluar dan pintu masuk dengan tepat dan dapat menghubungkan konsep-konsep yang dimiliki. Sedangkan pada soal nomor 3, subjek AD menggambar sketsa dengan posisi yang tidak tepat dan dilihat dari sudut pandang yang tidak tepat. Serta untuk soal nomor 4, subjek AD menjelaskan dengan baik alasan perbedaan volume kedua tenda dan dapat menghitung volume tenda pertama dengan tepat tetapi tidak tepat dalam menghitung volume tenda kedua.

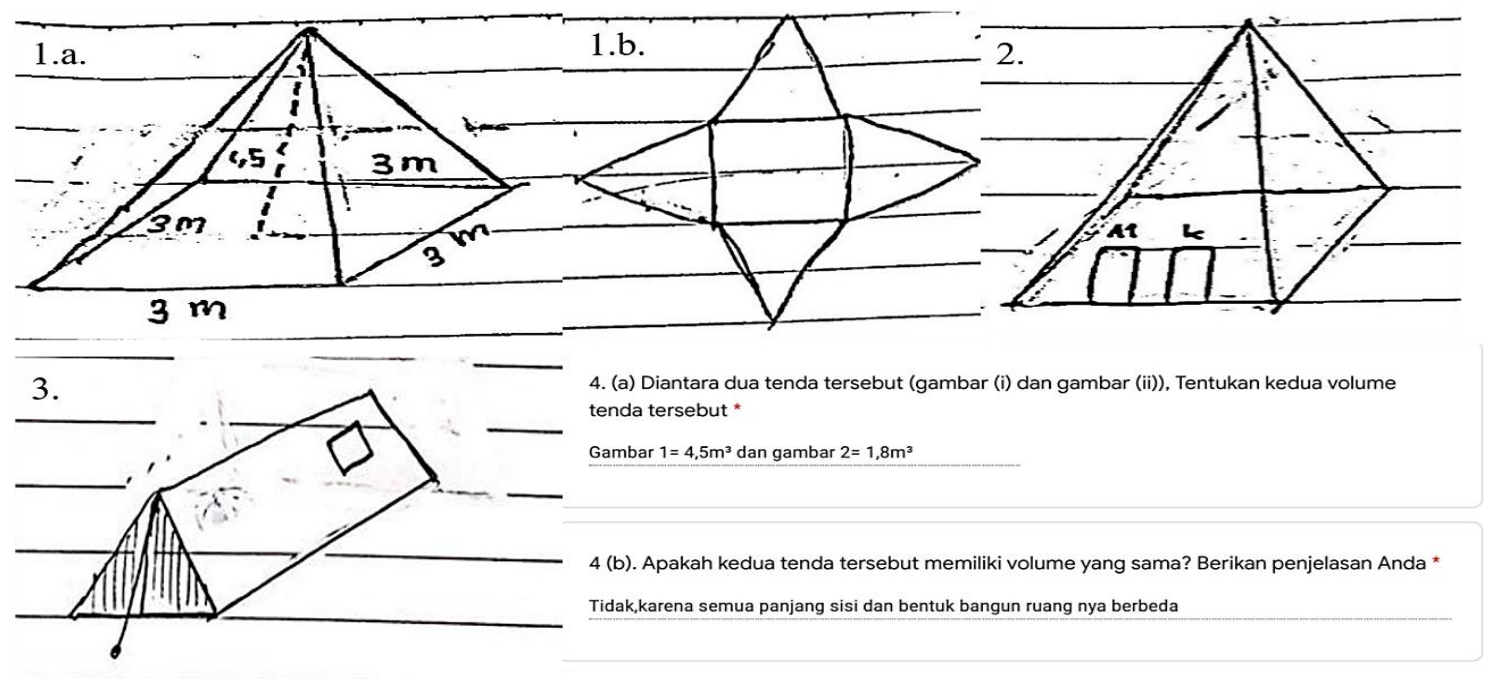

Gambar 2. Jawaban subjek AD pada soal nomor 1-4

Berdasarkan data hasil tugas-1 dengan wawancara-1 dan tugas-2 dengan wawancara-2 diperoleh bahwa kedua data tersebut cenderung sama, sehingga dapat disimpulkan bahwa data literasi spasial subjek $\mathrm{AD}$ dalam menyelesaikan soal-soal geometri adalahh valid. Hasil analisis wawancara subjek AD pada tugas-1 dan tugas-2 dapat disimpulkan siswa dapat menggambar sketsa bentuk tiga dimensi limas secara tepat dan lengkap dengan menuliskan ukuran setiap unsur berdasarkan informasi yang ditemukan pada soal. subjek juga dapat mengubah bentuk tiga dimensi menjadi bentuk dua dimensi, menyelesaikan soal menggunakan konsep, representasi, dan keknik yang melibatkan dimensi, serta menyampaikan ide-ide yang berkaitan dengan bangun tiga dimensi secara tulisan. Untuk lebih jelasnya dapat dilihat pada Tabel 3 .

Tabel 3. Profil literasi spasial subjek ad dalam menyelesaikan soal-soal geometri

\begin{tabular}{lll}
\hline No & Domain & Interpretasi Konvergensi \\
\hline 1 & Visualisasi & a. Menggambar sketsa bangun ruang limas dengan tepat berdasarkan \\
& Spasial & informasi yang didapatkan. \\
& & b. Menuliskan keterangan ukuran unsur-unsur dengan lengkap. \\
\hline
\end{tabular}


DOI: https://doi.org/10.24127/ajpm.v10i3.3650

\begin{tabular}{|c|c|c|}
\hline No & Domain & Interpretasi Konvergensi \\
\hline 2 & $\begin{array}{l}\text { Penalaran } \\
\text { Spasial }\end{array}$ & $\begin{array}{l}\text { c. Kurang konsisten dalam menuliskan satuan pada setiap unsur. } \\
\text { a. Memahami maksud dari bentuk dua dimensi } \\
\text { b. Mengubah serta menggambar sketsa bentuk dua dimensi dari bentuk } \\
\text { tiga dimensi dengan tepat dan proporsional. }\end{array}$ \\
\hline 3 & $\begin{array}{l}\text { Komunikasi } \\
\text { Spasial }\end{array}$ & $\begin{array}{l}\text { c. Menggambar sketsa pintu keluar dan pintu masuk dengan tepat } \\
\text { berdasarkan informasi dan ide yang diperoleh. } \\
\text { d. Menggambar sketsa tenda dengan posisi yang tidak tepat dan dilihat } \\
\text { dari sudut pandang yang tidak tepat. } \\
\text { a. Menyampaikan ide-ide yang berkaitan dengan bangun ruang } \\
\text { geometri secara tulisan dengan membuat alasan perbedaan kedua } \\
\text { volume. } \\
\text { b. Menghitung volume tenda pertama dengan tepat. } \\
\text { c. Menghitung volume tenda kedua dengan tidak tepat. }\end{array}$ \\
\hline
\end{tabular}

Berdasarkan data tersebut disimpulkan bahwa subjek AD dapat mengeksplor pengetahuannya melalui bahasa dimana subjek AD dapat menyampaikan dan menjelaskan ide-ide yang berkaitan dengan bentuk tiga dimensi dengan baik hal ini sejalan dengan penelitian (Hidayat, 2017) yang menyatakan bahwa siswa dengan gaya belajar auditori dapat mengeksplor proses berpikirnya dengan menemukan hal-hal baru dengan menggunakan bahsa mereka sendiri.

\section{Literasi Spasial Siswa Gaya Belajar Kinestetik}

Hasil literasi spasial siswa dalam menyelesaikan soal-soal penugasan geometri untuk subjek KT pada soal nomor satu sampai dengan nomor empat dapat dilihat pada Gambar 3.
Berdasarkan hasilnya, subjek KT dapat menyelesaikan soal ke-1 dan ke-2 dengan menggambar sketsa secara tepat tetapi tidak tepat dalam menuliskan ukuran salah satu unsur dikarenakan subjek menuliskan ukuran unsur tinggi pada garis tegak limas segiempat. Subjek KT mengubah bentuk tiga dimensi menjadi dua dimensi dengan tidak tepat. Pada soal nomor 2, subjek KT menggambar sketsa pintu keluar dan pintu masuk tidak berdampingan dan kedua pintu tersebut berada pada sisi yang berbeda. Sedangkan pada soal nomor 3, subjek KT menggambar sketsa dengan posisi yang tepat dan dilihat dari sudut pandang yang tepat. Serta untuk soal nomor 4, subjek KT menghitung dengan tepat volume tenda pertama dan volume tenda kedua, serta dapat menjelaskan dengan baik alasan perbedaan volume kedua tenda. 
DOI: https://doi.org/10.24127/ajpm.v10i3.3650

1.a.

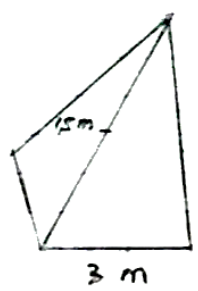

3.

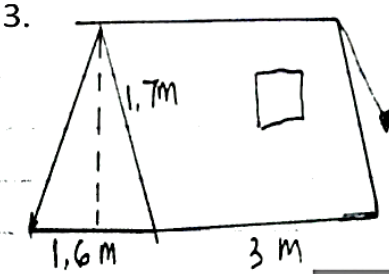

1.b.

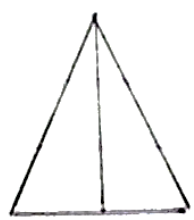

2.

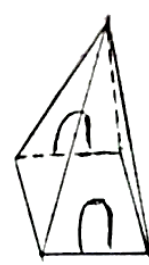

4. (a) Diantara dua tenda tersebut (gambar (i) dan gambar (ii)). Tentukan kedua volume tenda tersebut *

$\mathrm{i}=4.5 \mathrm{~m} * 3, \mathrm{i} * 3.6 \mathrm{~m} * 3$

4 (b). Apakah kedua tenda tersebut memiliki volume yang sama? Berikan penjelasan Anda

Tidak kedua tenda tersebur menilik volume yang betbeda

Gambar 3. Jawaban Subjek VS Pada Soal Nomor 1-4

Berdasarkan data hasil tugas-1 dengan wawancara-1 dan tugas-2 dengan wawancara-2 diperoleh bahwa kedua data tersebut cenderung sama, sehingga dapat disimpulkan bahwa data literasi spasial subjek KT dalam menyelesaikan soal-soal geometri adalahh valid. Hasil analisis wawancara subjek KT pada tugas-1 dan tugas-2 dapat disimpulkan siswa dapat menggambar sketsa bentuk tiga dimensi limas secara tepat dan lengkap dengan menuliskan ukuran setiap unsur berdasarkan informasi yang ditemukan pada soal, menyelesaikan soal menggunakan konsep, representasi, dan keknik yang melibatkan dimensi sesuai dengan imajinasi subjek, serta menyampaikan ide-ide yang berkaitan dengan bangun tiga dimensi secara tulisan. Untuk lebih jelasnya dapat dilihat pada Tabel 4.

Tabel 4. Profil literasi spasial subjek KT dalam menyelesaikan soal-soal geometri

\begin{tabular}{|c|c|c|}
\hline No & Domain & Interpretasi Konvergensi \\
\hline 1 & $\begin{array}{l}\text { Visualisasi } \\
\text { Spasial }\end{array}$ & $\begin{array}{l}\text { a. Menggambar sketsa bangun ruang limas dengan tepat berdasarkan } \\
\text { informasi yang didapatkan. } \\
\text { b. Menuliskan keterangan ukuran unsur-unsur bangun ruang limas } \\
\text { dengan tidak tepat } \\
\text { c. Konsisten dalam menuliskan satuan pada setiap unsur. }\end{array}$ \\
\hline 2 & $\begin{array}{l}\text { Penalaran } \\
\text { Spasial }\end{array}$ & $\begin{array}{l}\text { a. Menjelaskan maksud bentuk dua dimensi menggunakan imajinasi } \\
\text { dan pemikiran subjek sendiri. } \\
\text { b. Mengubah serta menggambar sketsa bentuk dua dimensi dari } \\
\text { bentuk tiga dimensi dengan tidak tepat. } \\
\text { c. Menggambar sketsa pintu keluar dan pintu masuk tidak } \\
\text { berdampingan dan empunyai sisi berbeda. } \\
\text { d. Menggambar sketsa tenda dengan posisi yang tepat dan dilihat dari } \\
\text { sudut pandang yang tepat. }\end{array}$ \\
\hline 3 & $\begin{array}{l}\text { Komunikasi } \\
\text { Spasial }\end{array}$ & $\begin{array}{l}\text { a. Menyampaikan ide-ide yang berkaitan dengan bangun ruang } \\
\text { geometri secara tulisan dengan membuat alasan perbedaan kedua } \\
\text { volume. } \\
\text { b. Menghitung volume tenda pertama dengan tepat. } \\
\text { c. Menghitung volume tenda kedua dengan tepat. }\end{array}$ \\
\hline
\end{tabular}

Berdasarkan data yang disajikan, disimpulkan bahwa literasi spasial subjek KT masih kurang berkembang pada domain penalaran spasial. Hal ini 
sejalan dengan penelitian (MooreRusso,et.al.2013) bahwa kemampuan literasi spasial guru mempunyai banyak kekurangan dalam memecahkan masalah pada domain penalaran. Selain itu subjek KT dapat mengeksplor pengetahuan dan menemukan hal-hal baru seperti memiliki pemikiran yang berbeda dengan subjek VS dan AD mengenai maksud dari bentuk dua dimensi. Hal ini sejalan dengan penelitian (Hidayat, 2017) yang menyatakan bahwa siswa dengan gaya belajar kinestetik melalui proses berpikir spasial secara tidak teratur dan dapat mengeksplor pengetahuannya dan menemukan hal baru dalam berpikir spasial.

Pada penelitian ini ditemukan beberapa temuan yaitu Subjek visual (VS) dalam menuliskan keterangan ukuran setiap unsur-unsur bangun tiga dimensi berdasarkan informasi yang diperoleh pada soal, subjek meuliskan ukuran unsur-unsurnya dengan lengkap dan detail baik yang didapatkan pada informasi soal maupun yang tidak didapatkan di informasi soal pada bangun dua dimensi dan bangun ruang tiga dimensi dengan mencari atau menghitungnya. Selain itu subjek visual dan kinestetik membuat gambar sketsa tenda secara lengkap besert tali tenda.

\section{KESIMPULAN DAN SARAN}

Berdasarkan hasil penelitian dapat disimpulkan secara keseluruhan bahwa literasi spasial pada siswa gaya belajar visual tergolong baik pada domain visualisasi dan penalaran spasial, tetapi masih lemah pada domain komunikasi spasial. Sedangkan siswa dengan gaya belajar auditori tergolong baik pada visualisasi spasial dan komunikasi spasial. Pada komunikasi spasial siswa auditori mampu menjelaskan baik secara tulisan maupun secara lisan alasan kedua tenda memiliki volume yang berbeda, sayangnya siswa auditori memiliki kelamahan pada penalaran spasial. Sedangkan siswa dengan gaya belajar kinestetik memiliki kelamahan pada penalaran spasial tetapi siswa kinestetik dapat menemukan hal baru atau memiliki imajinasi yang lebih unggul daripada siswa auditori dan visual. Siswa kinestetik juga tergolong baik dalam komunikasi spasial terutama dalam menghitung volume kedua tenda.

Adapun saran yang dapat dilakukan untuk penelitian selanjutnya adalah para pengajar matematika sebaiknya memberikan alasan atau pendapat pada soal yang diberikan sehingga siswa terbiasa tidak hanya menghitung tetapi juga terbiasa dalam memberikan pendapat, dan untuk para peneliti selanjutnya yang akan meneliti dengan tema yang sama sebaiknya dalam memberikan TKM dan penugasan dilakukan secara langsung dan tidak melalui daring sehingga memperoleh data yang lebih lengkap dan detail.

\section{DAFTAR PUSTAKA}

Abidin, Y., Mulyati, T., \& Yunansah, H. (2017). Pembelajaran Literasi Strategi Meningkatkan Kemampuan Literasi Matematika, Sains, Membaca, dan Menulis. Jakarta: Bumi Aksara.

Alfaruqi, A. I., \& Lutfianto, M. (2018). Perbandingan Kemampuan Spasial Siswa SMA Pada Materi Geometri Ditinjau Dari Gaya Belajar Siswa. Prosiding Seminar Nasional Pendidikan Matematika Ahmad Dahlan (Vol. 1, pp. 1317).

Bednarz, S. W., \& Kemp, K. (2011). Understanding and nurturing spatial literacy. Procedia-Social and Behavioral Sciences, 21, 1823. Diakses dari www.sciencedirect.com. 
Budiarto, M. T., \& Artiono, R. (2019). Geometri Dan Permasalahan Dalam Pembelajarannya (Suatu Penelitian Meta Analisis). JUMADIKA: Jurnal Magister Pendidikan Matematika, 1(1), 918.

DePorter, B., Reardon, M., \& SingerNourie, S. (2014). Quantum teaching: mempraktikkan quantum learning di ruang-ruang kelas. Bandung: Kaifa.

Fitri, N. (2017). Profil Kemampuan Spasial Siswa SMA dalam Memecahkan Masalah Geometri Ditinjau dari Gaya Belajar (Doctoral dissertation, UIN ArRaniry Banda Aceh).

Hidayat, K. N. (2017). The Analisis Proses Berfikir Spasial Siswa Pada Materi Geometri Ditinjau Dari Gaya Belajar. Prosiding SI MaNIs (Seminar Nasional Integrasi Matematika dan NilaiNilai Islami) (Vol. 1, No. 1, pp. 385-394)

Jarvis, C. H. (2011). Spatial literacy and the postgraduate GIS curriculum. Procedia-Social and Behavioral Sciences, 21, 294-299.

Lane, D., Lynch, R., \& McGarr, O. (2019). Problematizing spatial literacy within the school curriculum. International Journal of Technology and Design Education, 29(4), 685-700.

Lowrie, T., Logan, T., Harris, D., \& Hegarty, M. (2018). The impact of an intervention program on students' spatial reasoning: Student engagement through mathematics-enhanced learning activities. Cognitive research: principles and implications, 3(1), 1-10.

Maulana, A. (2017). Deskripsi Kemampuan Literasi Matematika
Siswa Kelas Viii-2 Smp Negeri 15

Kendari. Jurnal Penelitian Pendidikan Matematika, 4(2), 114.

Moore-Russo, D., Viglietti, J. M., Chiu, M. M., \& Bateman, S. M. (2013). Teachers' spatial literacy as visualization, reasoning, and communication. Teaching and Teacher Education, 29, 97-109.

Mulligan, J. (2015). Looking within and beyond the geometry curriculum: connecting spatial reasoning to mathematics learning. ZDM, 47(3), 511-517.

Nja, C. O., Umali, C. U. B., Asuquo, E. E., \& Orim, R. E. (2019). The influence of learning styles on academic performance among science education undergraduates at the University of Calabar. Educational Research and Review, 14(17), 618-624.

Piacentini, M., \& Monticone, C. (2016). Equations and Inequalities: Making Mathematics Accessible to All. PISA. OECD Publishing. 2, rue Andre Pascal, F-75775 Paris Cedex 16, France.

Subaidah, S., Valentino, E., \& Wijayanti, E. (2017). Analisis Literasi Matematika Siswa Dalam Memecahkan Soal Matematika Pisa Konten Ruang Dan Bentuk. Buana Matematika: Jurnal Ilmiah Matematika dan Pendidikan Matematika, 7(1), 7-12.

Yusmin, E. (2016). Proses Literasi Matematis Dikaji Dari Content Space and Shape Dalam Materi Geometri di SMA. Jurnal Pendidikan dan Pembelajaran Khatulistiwa, 5(11). 